\title{
Severe paradoxical disease activation following alemtuzumab treatment for multiple sclerosis
}

Jamie Brannigan, Joanne L. Jones, MB ChB, PhD, and Sybil R. L. Stacpoole, MB BChir, PhD

Neurol Neuroimmunol Neuroinflamm 2020;7:e799. doi:10.1212/NXI.0000000000000799

\author{
Correspondence \\ Dr. Stacpoole \\ srls2@cam.ac.uk
}

A 39-year-old right-handed agricultural service engineer developed rapidly evolving severe relapsing-remitting multiple sclerosis (MS). MRI showed multiple T2 hyperintensities throughout his neuroaxis (figure, A). Several lesions showed restricted diffusion, and 2 enhanced. He received steroids for each relapse, making a full recovery (Expanded Disability Status Score [EDSS] 0).

There was clinical equipoise between induction therapy with alemtuzumab or natalizumab. $\mathrm{He}$ was JC virus positive. He chose treatment with alemtuzumab, partly because of the even chance that after 2 cycles, he might not require further treatment, plus the ease of administration, vs the longer-term risks with natalizumab.

Nine months after the first cycle of alemtuzumab, he represented with an encephalopathic picture and progressive focal neurology. He had a headache for 12 days, diplopia for 8 days, and became confused and unsteady on his feet over 5 days. He was apyrexial, looked unwell, was drowsy, and disorientated. Diplopia was present in all directions, and he had mild left upper motor neurone facial weakness and proximal weakness of his lower limbs. Reflexes were difficult to elicit, with upgoing plantars. He deteriorated markedly over the subsequent week, developing ophthalmoplegia, tetraparesis, inability to communicate, and respiratory compromise requiring intubation (EDSS 9.5).

Serum and CSF markers of infection were all negative, including listeria, but his CSF was active with significantly elevated lymphocytes $\left(200\right.$ cells $/ \mathrm{mm}^{3} ; 90 \%$ lymphocytes $)$ and protein $(0.85$ $\mathrm{g} / \mathrm{L})$; glucose was normal. CSF showed unmatched oligoclonal bands. Aquaporin-4 and MOG antibodies were negative.

CSF cytology confirmed reactive lymphocytes (85\%). Flow cytometry reported $59 \% \mathrm{~T}$ cells (CD4:CD8 2:1), 35\% B cells (kappa:lambda 1.4:1), and 3\% NK cells. An additional 13\% had a larger morphology and phenotype profile consistent with plasma cells, strongly expressing $\mathrm{CD} 45$ and $\mathrm{CD} 38$, moderately expressing $\mathrm{CD} 81^{+}$, and weakly expressing $\mathrm{CD} 19$ and light chains.

Repeat brain MRI revealed numerous new white matter lesions. Most showed restricted diffusion, suggestive of acute demyelination (figure, B), but there was no enhancement (postgadolinium images not shown). EEG showed nonspecific generalized slowing, consistent with generalized cerebral dysfunction/encephalopathy.

His presentation was consistent with encephalitis, with an infective or inflammatory cause. Acyclovir, ceftriaxone, and amoxicillin were administered early, followed by $3,000 \mathrm{mg}$ IV methylprednisolone over 3 days and 10 cycles of alternate day plasma exchange.

There was no clinical response, and repeat MRI brain showed progression (figure, C), still without contrast enhancement (not shown). Severe B cell-mediated demyelination was

From Jesus College (J.B., S.R.L.S.), Cambridge University, UK; Department of Neurology (J.L.J., S.R.L.S.), Addenbrooke's Hospital, Cambridge University Hospitals NHS Foundation Trust, Cambridge, UK; and Department of Neurology (S.R.L.S.), Peterborough City Hospital, North West Anglia NHS Foundation Trust, Peterborough, UK.

Go to Neurology.org/NN for full disclosures. Funding information is provided at the end of the article.

The Article Processing Charge was funded by the Wellcome Trust.

This is an open access article distributed under the terms of the Creative Commons Attribution License 4.0 (CC BY), which permits unrestricted use, distribution, and reproduction in any medium, provided the original work is properly cited. 

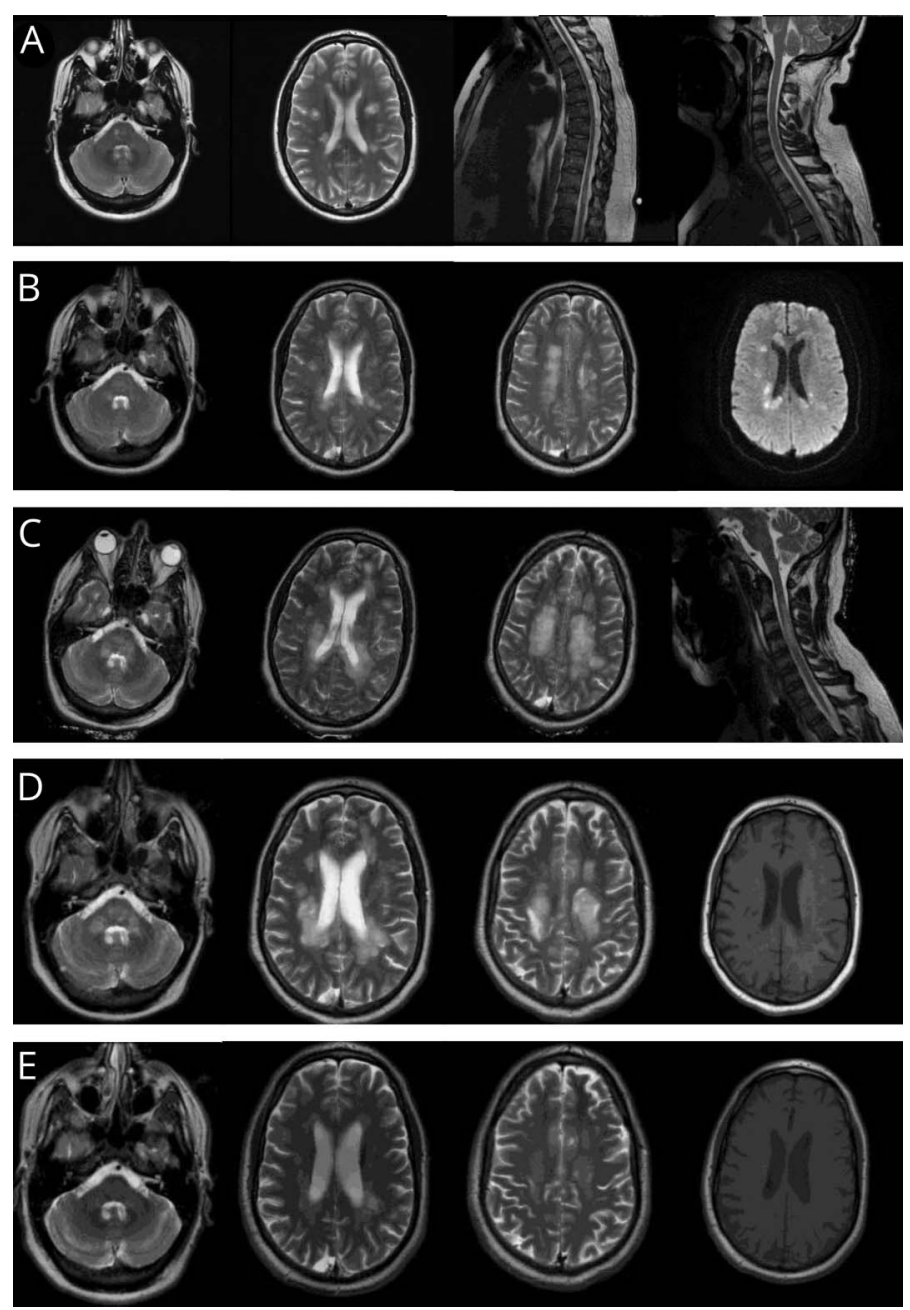

(A) MRI of the brain and spinal cord at the point of diagnosis with rapidly evolving relapsing-remitting MS. His initial demyelinating event involved the brainstem and medial longitudinal fasciculus with several areas of involvement in the cerebral cortex. The second event localized to the lower spinal cord, with no evidence of involvement of the cervical spine. (B) MRI of the brain the day after representation, 9 months after the first cycle of alemtuzumab. T2-weighted imaging showed multiple new areas throughout the brain. Diffusion-weighted imaging confirmed appearances suggestive of acute demyelination with multiple areas of restricted diffusion. (C) MRI of the brain and cervical spine 3 weeks after representation. T2-weighted images show extensive demyelination in the brainstem, cerebral cortex, and cervical spine. (D) MRI of the brain at nadir, 5 weeks after representation. T2-weighted imaging illustrates extensive demyelination with areas of T1 signal change. (E) MRI of the brain 17 months later showing remarkable resolution over time. suspected. Rituximab was commenced and continued 6 monthly, alongside 3 cycles of cyclophosphamide. Subsequent gradual improvement resulted in a remarkable functional recovery (EDSS 3.5 two years later with return to full time work) along with significant remyelination and resolution of T1 black holes (figures, D and E).

\section{Discussion}

The first 2 cases of paradoxical disease activation in patients with MS treated with alemtuzumab were reported in 2017 . $^{1}$ The authors proposed that a secondary B cell-driven autoimmune disease targeting the CNS and appearing similar to MS could occur after alemtuzumab therapy due to the observation that B-cell numbers recover far more quickly after alemtuzumab than $\mathrm{CD}^{+}$and $\mathrm{CD}^{+} \mathrm{T}$ cells, sometimes overshooting pretreatment levels. ${ }^{1}$ However, the relative kinetics of $\mathrm{B}$ - and $\mathrm{T}$-cell recovery have no effect on the risk of non-CNS-directed autoimmunity. Rather, the risk of developing Graves disease and immune thrombocytopenia after alemtuzumab is associated with poor thymic T-cell recovery and exaggerated $\mathrm{CD} 4^{+} \mathrm{T}$-cell homeostatic proliferation. ${ }^{2} \mathrm{CNS}$ directed alemtuzumab-induced autoimmunity is also unlikely to be due to numerical differences in B- and T-cell counts. Instead, this acute disseminated encephalomyelitis-like illness after alemtuzumab is more likely to result from the complex interplay of multiple reconstituting immune cell subsets.

Eleven of the other 17 reported cases of disease activation after alemtuzumab occurred in those switching therapies directly from fingolimod, ${ }^{1,3,4}$ suggesting confounding of pathologic mechanisms. Following treatment with fingolimod, many lymphocytes remain hidden from the intravascular therapeutic effects of alemtuzumab due to selective lymphoid sequestration. Later egression could initiate rebound activity, which also occurs if fingolimod treatment is stopped without substituting a different therapy. ${ }^{3}$ This disease activity would be due to a failure of alemtuzumab to bind to $\mathrm{CD} 52^{+-}$ lymphocytes, not the repopulation kinetics of $\mathrm{B}$ and $\mathrm{T}$ cells after treatment. 
One question on encountering paradoxical disease activation after alemtuzumab is whether to proceed to the second treatment cycle or switch to rituximab (or an alternative antiCD20 B-cell therapy such as ocrelizumab). Five patients in the literature received rituximab; 6 including ours. All have responded well. Willis' case series of disease activity 4-5 months post-alemtuzumab in patients switched from fingolimod responded well to the second cycle of alemtuzumab, as might be expected from the mechanisms discussed above.

We hope that the remarkable recovery of our patient, despite extensive brainstem involvement, will provide clinicians with the confidence to treat in such severe situations.

\section{Study funding}

No targeted funding was provided. J.L. Jones is supported by the Wellcome Trust (RG49413).

\section{Disclosure}

J. Brannigan and S.R.L. Stacpoole report no disclosures relevant to the manuscript. J.L. Jones has received honoraria from Sanofi-Genzyme. Go to Neurology.org/NN for full disclosures.

\section{Publication history}

Received by Neurology: Neuroimmunology \& Neuroinflammation January 6, 2020. Accepted in final form April 22, 2020.

\section{Appendix Authors}

\begin{tabular}{|c|c|c|}
\hline Name & Location & Contribution \\
\hline $\begin{array}{l}\text { Jamie } \\
\text { Brannigan }\end{array}$ & $\begin{array}{l}\text { Jesus College, Cambridge } \\
\text { University, UK }\end{array}$ & $\begin{array}{l}\text { Drafted the manuscript, } \\
\text { analyzed data, and } \\
\text { literature review }\end{array}$ \\
\hline $\begin{array}{l}\text { Joanne } \\
\text { Jones, MB } \\
\text { ChB, PhD }\end{array}$ & $\begin{array}{l}\text { Department of Neurology, } \\
\text { Addenbrooke's Hospital, } \\
\text { Cambridge University } \\
\text { Hospitals NHS Foundation } \\
\text { Trust, Cambridge, UK }\end{array}$ & $\begin{array}{l}\text { Interpreted the data and } \\
\text { revised the manuscript } \\
\text { for intellectual content }\end{array}$ \\
\hline $\begin{array}{l}\text { Sybil } \\
\text { Stacpoole, } \\
\text { MB BChir, } \\
\text { PhD }\end{array}$ & $\begin{array}{l}\text { Jesus College, Cambridge } \\
\text { University, UK } \\
\text { Department of Neurology, } \\
\text { Addenbrooke's Hospital, } \\
\text { Cambridge University } \\
\text { Hospitals NHS Foundation } \\
\text { Trust, Cambridge, UK } \\
\text { Department of Neurology, } \\
\text { Peterborough City Hospital, } \\
\text { North West Anglia NHS } \\
\text { Foundation Trust, } \\
\text { Peterborough, UK }\end{array}$ & $\begin{array}{l}\text { Lead physician caring for } \\
\text { the patient, data } \\
\text { acquisition, and revised } \\
\text { the manuscript for } \\
\text { intellectual content }\end{array}$ \\
\hline
\end{tabular}

\section{References}

1. Haghikia A, Dendrou CA, Schneider R, et al. Severe B-cell-mediated CNS disease secondary to alemtuzumab therapy. Lancet Neurol 2017;16:104-106.

2. Jones JL, Thompson SAJ, Loh P, et al. Human autoimmunity after lymphocyte depletion is caused by homeostatic T-cell proliferation. Proc Natl Acad Sci U S A 2013;110:20200-20205.

3. Willis M, Pearson O, Illes Z, et al. An observational study of alemtuzumab following fingolimod for multiple sclerosis. Neurol Neuroimmunol Neuroinflamm 2017;4: e320. doi:10.1212/NXI.0000000000000320.

4. Wehrum T, Beume LA, Stich O, et al. Activation of disease during therapy with alemtuzumab in 3 patients with multiple sclerosis. Neurology 2018;90:e1-e5. 


\section{Neurology \\ Neuroimmunology \& Neuroinflammation}

Severe paradoxical disease activation following alemtuzumab treatment for multiple sclerosis

Jamie Brannigan, Joanne L. Jones and Sybil R. L. Stacpoole

Neurol Neuroimmunol Neuroinflamm 2020;7;

DOI 10.1212/NXI.0000000000000799

This information is current as of June 10, 2020

Neurol Neuroimmunol Neuroinflamm is an official journal of the American Academy of Neurology.

Published since April 2014, it is an open-access, online-only, continuous publication journal. Copyright

Copyright (C) 2020 The Author(s). Published by Wolters Kluwer Health, Inc. on behalf of the American

Academy of Neurology.. All rights reserved. Online ISSN: 2332-7812.

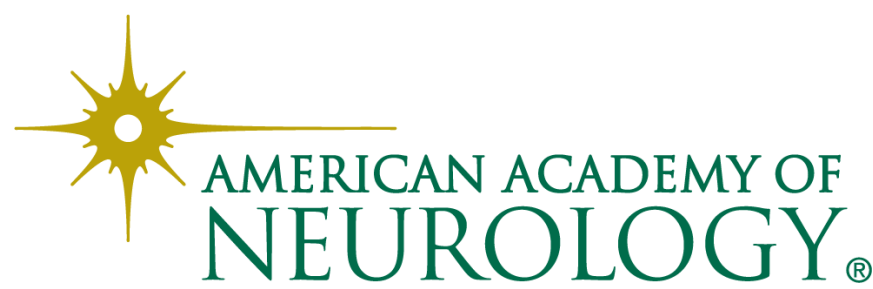




\section{Updated Information \& Services}

References

Citations

Subspecialty Collections

Permissions \& Licensing

Reprints including high resolution figures, can be found at:

http://nn.neurology.org/content/7/5/e799.full.html

This article cites 4 articles, 2 of which you can access for free at: http://nn.neurology.org/content/7/5/e799.full.html\#\#ref-list-1

This article has been cited by 1 HighWire-hosted articles: http://nn.neurology.org/content/7/5/e799.full.html\#\#otherarticles

This article, along with others on similar topics, appears in the following collection(s):

Acute disseminated encephalomyelitis

http://nn.neurology.org//cgi/collection/acute_disseminated_encephalo myelitis

Autoimmune diseases

http://nn.neurology.org//cgi/collection/autoimmune_diseases Encephalitis

http://nn.neurology.org//cgi/collection/encephalitis

Multiple sclerosis

http://nn.neurology.org//cgi/collection/multiple_sclerosis

Information about reproducing this article in parts (figures,tables) or in its entirety can be found online at:

http://nn.neurology.org/misc/about.xhtml\#permissions

Information about ordering reprints can be found online: http://nn.neurology.org/misc/addir.xhtml\#reprintsus

Neurol Neuroimmunol Neuroinflamm is an official journal of the American Academy of Neurology.

Published since April 2014, it is an open-access, online-only, continuous publication journal. Copyright

Copyright $\odot 2020$ The Author(s). Published by Wolters Kluwer Health, Inc. on behalf of the American Academy of Neurology.. All rights reserved. Online ISSN: 2332-7812.

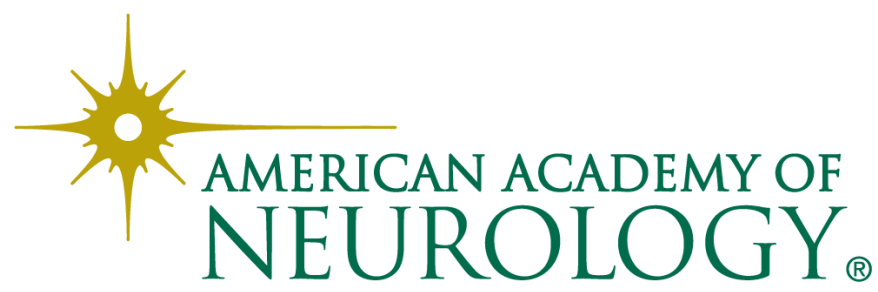

